\title{
COMPARATIVE STUDY OF CERTAIN INSECTICIDES AND THE MIXTURES OF SOME PLANT OILS AGAINST COTTON LEAFWORM Spodoptera littoralis (BOISD)
}

\author{
Ragaa A. Sayed ${ }^{*}$; H.M. Mahfouz ${ }^{2}$; M.M. Ali ${ }^{1}$ and M.N. El-Basiony ${ }^{2}$
}

1. Inst. Plant Prot. Res., Cent. Agric. Res., Egypt.

2. Dept. Plant Prod., Fac. Environ. Agric. Sci, Arish Univ., Egypt.

\begin{abstract}
Laboratory experiments were conducted under controlled conditions to test the insecticidal activity of two insecticides i.e. Cypermethrin (25\% E.C) a synthetic pyrethroid and Chlorpyrifos (48\% E.C) an organophosphate insecticide. Also five plant oils were used in a ratio $(1: 1)$ i.e $(v / v)$ and they were as in following: Menth piperita L., Syzygium aromaticum L., Cinnamomum camphora L., Allium sativum L. and Anethum graveolens L. The $4^{\text {th }}$ instar larvae was used in bioassay of these insecticides and oils alone and the mixture of (insecticide: oil). The acute toxicity $\left(\mathrm{LC}_{50}\right)$ of each treatment recorded after $120 \mathrm{hr}$. Also the toxicity index (T.I) and relative potency (R.P) were calculated. The results showed that cypermethrin is more toxic than chlorpyrifos, also the Allium sativum L. was the most toxic oil and the lowest one was oil Syzygium aromaticum L. Finally the most toxic mixture was with cypermethrin, especially the mixture of cypermethrin and Allium sativum L. (1:1).
\end{abstract}

Key words: Insecticidal activity, cypermethrin, chlorpyrifos, plant oils, Menth piperita L., Syzygium aromaticum L., Cinnamomum camphora L., Allium sativum L. Anethum graveolens L. $4^{\text {th }}$ instar larvae of cotton leafworm Spodoptera littoralis (Boisd) and Mixtures of oil plant.

\section{INTRODUCTION}

According to Conway et al. (1982), today there are more than 432 species of insects, mites, or ticks which were recorded as resistant to insecticides or acaricides, of these species, 216 are agricultural pests .The rate of resistance development and frequency depend on many genetic and biological factors. Also El-Sebae (1987), reported that, insect pests with potential rate of reproduction such as insect (cotton leafworm, aphids, spider mites ... etc.) are notorious for developing resistance. However the overriding factor is the selection pressure exerted by high and frequent rates of pesticide application. Resistance had developed to all insecticide groups. In a lot of early studies the use of mixtures of some promising plant oils and plant extracts (e.g Camphor - Garlic - Clove - Dill - Citrus.etc.) and various insecticides belonging to different chemical groups (e.g: O.P's-Carbamates and Synthetic pyrethroids). These mixtures applied on many pests (cotton leafworm - stored grain pests - cut worm - soya bean borers- citrus leaf minorCulex pipens ... etc). The use of these mixtures and the aim of these control tactics were studied by many authers, Lichtenstein et al. (1974), Eldoksch et al. (1991), Guirguis et al. (1991), Taman (2002) and Hussein et al. (2005). So the aim of that study was an attempt to use the tested mixtures of plant oils and the lowest amount of synthetic insecticides to be applied instead of using synthetic insecticides with its recommended concentration and amount

\footnotetext{
* Corresponding author: Tel.: +201227655804

E-mail address: dr.ragaa73@gmail.com
} 
for enhancing the minimizing and rationalizing the use of synthetics as it is possible.

\section{MATERIALS AND METHODS}

\section{Rearing the tested insect}

The cultured of Cotton leafworm, Spodoptera littoralis (Boisd) used in this study originated from egg masses obtained from susceptible strain established in the laboratory of Dept. Environ. Prot., Fac. Environ. Agric. Sci., Arish Univ., North Sinai, Egypt. The progency of the insects together with occasional fresh supplies of egg formed the basis of culture designed to provide insects used in the present investigation. Five replicates per each concentration were used and 50 larvae/ Treatment. The $4^{\text {th }}$ instar larvae was used in the bioassay tests. Under lab. conditions of $25 \pm 2{ }^{\circ} \mathrm{C}$ (Temperature) and $60 \pm 5 \% \mathrm{RH}$ (Relative Humidity) El-Defrawy et al. (1964).

\section{Agrochemicals used in the study}

1- Cypermethrin $25 \%$ E.C [RS - $\alpha$-cyano -3phenoxy benzl (RS, CIS-trans) -3- (2.2dichloro vinyl) -2-2 dimethyl cycopropane carboxylate] (Pesticide manual Seventh Ed.1983).

2- Chlorpyrifos 48\% E.C [o,o-diethyl o-3,5,6trichloro-2pyridylphosphorothioate]

[Pesticide manual seventh Ed.1983]

Commercial formulations of tested insecticides were obtained from Central Agricultural Pesticides Laboratory (CAPL) in Dokki, Egypt, Giza.

\section{Chemical used in the study}

Bioassay of tested Plant Oils against $4^{\text {th }}$ Instar Larvae of Spodoptera littoralis (Boisd)

The tested plant oils used were as in the Table 1. A series of concentrations of each plant oil were prepared by dilutions with Triton X-100 (T-X100). A 100 larvae of $4^{\text {th }}$ instar were used for bioassay using five replicates for each concentration or (treatment) per each plant-oil and by using a dipping disc method of castor bean leaves for $30 \mathrm{sec}$ 's and left to dryness before used in bioassay. The (\%) mortality calculated every $24 \mathrm{hr}$. and for $120 \mathrm{hrs}$. The $\mathrm{LC}_{50}$ values, slopes and its confidence limits were obtained from the regression lines according to Finney (1971).

Bioassay of Tested Insecticides against $4^{\text {th }}$ Instar larvae of Spodoptera littoralis (Boisd)

A series of concentrations of the two formulated insecticides i.e., Chlorpyrifos $48 \%$ E.C and Cypermethrin 25\% E.C were prepared by dilution with dist. water and by using dipping disc method of castor bean leaves and 100 larvae of $4^{\text {th }}$ instar larvae of $S$. littoralis (Boisd) were used for the bioassay, in five replicates for each concentration (treatment) for each tested insecticide. The (\%) mortality recorded every $24 \mathrm{hrs}$. and for $120 \mathrm{hrs}$. The $\mathrm{LC}_{50}$ values, slopes and its confidence limits were obtained from the regression lines according to Finney (1971).

Bioasssay of Tested Mixtures of Insecticides: Plant Oils Against $4^{\text {th }}$ Instar Larvae of Spodoptera littoralis (Boisd).

A mixture of each insecticide plant oils were prepared by using T-X100 for preparing a series of concentrations also 100 larvae of $4^{\text {th }}$ instar larvae of $S$. littoralis were used for the bioassay. By using five replicates for each concentration or (treatment) for each tested mixture and applying a dipping disc method. The (\%) mortality recorded every $24 \mathrm{hr}$. and for 120 hr. The $\mathrm{LC}_{50}$ values, slopes and its confidence limits were obtained from the regression lines according to (Finney 1971). 
SINAI Journal of Applied Sciences (ISSN: 2314-6079) Vol. (6) Is. (2), Aug. 2017

Table (1): The list of tested plant oils.

\begin{tabular}{clcc}
\hline No. & \multicolumn{1}{c}{ Scientific Name } & English Name & Family \\
\hline 1 & Menth piperitaL. & Mint Oil & Lamiaceae \\
\hline 2 & Syzygium aromaticumL. & Clove Oil & Myrtaceae \\
\hline 3 & Cinnamomum camphoraL. & Camphor Oil & Lauraceae \\
\hline 4 & Allium sativumL. & Garlic Oil & Amaryllidaceae \\
\hline 5 & Anethum graveolens $\mathrm{L}$. & Dill Oil & Apiaceae \\
\hline
\end{tabular}

They were purchased from local market [El- Captain- company i.e a commercial producer of plant oils.

Solvents: chemical pure grade of Ethyl alcohol and acetone (95\%) purchased from ADWIC chemicals.

Non Ionic surfactant: Triton X-100 (BDH) [Isooctyl phenoxy-polyethoxyethanol] containing (10 mols of ethylene oxide).

\section{RESULTS}

Acute Toxicity of Tested Plant Oils against $4^{\text {th }}$ Instar Larvae of Cotton leafworm Spodoptera littorlis (Boisd).

Results presented in Table 2 comprise the $\mathrm{LC}_{50}$ values, where it arranged in a descending order as in the following: (1261, 1055.5, 1000, 883.3 and $763 \mathrm{ppm);}$ representing the plant oils as following: (C. camphora, S. aromaticum, M. piperita, A. graveolens and A. sativum) in other words the toxicity of the plant oils was the highest at $763 \mathrm{ppm}$, followed by 883.3 , $1000,1055.5$ and $1261 \mathrm{ppm}$ representing the plant oils as in the following: (A. sativum, A. graveolens, $M$. piperita, $S$. aromaticum and $C$. camphora) respectively. The values of toxicity index (T.I) were arranged in a descending order as in the following: $[A$. sativum (100), A.graveolens (86.4), $M$. piperita (76.3), $S$. aromaticum (72.3) and C.camphora (60.5)] i.e. the A. sativum has the highest value of T.I (100) and $C$. camphora has the lowest value of T.I (60.5). Also the relative potency (R.P) achieved a similar trend of arrangement in a descending order as following: A. sativum (165.3), A. graveolens (142.8), M. piperita (126.1), C.camphora (100) i.e., the $A$. sativum has the highest R.P (165.3) and the C. camphora has the lowest R.P (100).

Acute Toxicity of Tested Insecticides against $4^{\text {th }}$ Instar Larvae of cotton leafworm $\boldsymbol{S}$. littorlis (Boisd).

Results recorded in Table 3 show that the Cypermethrin is more toxic than Chlorpyrifos and showing $\mathrm{LC}_{50}$ values as following: 10 and 33.33ppm respectively.

Acute Toxicity of Tested Mixture (1:1) of Cypermethrin 25\% E.C and Five PlantOils against $4^{\text {th }}$ Instar Larvae of cotton leafworm Spodoptera littoralis (Boisd).

Results in Table 4 show that $\mathrm{LC}_{50}$ values were arranged in a descending order as follow, Mixture of (Cypermethrin + Camphor oil), Mixture of (Cypermethrin + Clove oil), Mixture of (Cypermethrin + Mint oil), Mixture of (Cypermethrin + Dill oil) and Mixture of (Cypermethrin + Garlic oil) causing the following $\mathrm{LC}_{50}$ values: (938.9, 736.7, 469.4, 426.1 and $382.8 \mathrm{ppm})$ respectively So, by other words the highest toxic mixture was that of (Cypermethrin + Garlic oil) leading to $\mathrm{LC}_{50}$ equal to 382.8 ppm and the lowest toxic mixture was that of : (Cypermethrin + Camphor oil) showing a $\mathrm{LC}_{50}$ equal to $938.9 \mathrm{ppm}$. The toxicity index values were arranged in a descending order as in the following: [A. sativum (100), 
Table (2): Acute toxicity of tested (Plant oils) against $4^{\text {th }}$ instar larvae of cotton leafworm, Spodoptera littoralis (Boisd).

\begin{tabular}{llccccc}
\hline No. & \multicolumn{1}{c}{ Treatment } & $\begin{array}{c}\text { Lc }_{\mathbf{5 0}} \\
\mathbf{p p m})\end{array}$ & Slope & $\begin{array}{c}\text { Confidence } \\
\text { limits of } \mathbf{L C}_{\mathbf{5 0}}\end{array}$ & $\begin{array}{c}\text { Toxicity } \\
\text { index }\end{array}$ & $\begin{array}{c}\text { Relative } \\
\text { potency at fold }\end{array}$ \\
\hline 1 & Menth piperita L. & 1000 & 0.633 & $840-1195$ & 76.3 & 126.1 \\
2 & Syzygium aromaticum L. & 1055.5 & 0.503 & $727.9-1208.6$ & 72.3 & 119.5 \\
3 & Cinnamomum camphora L. & 1261 & 0.571 & $1096-1452$ & 60.5 & 100 \\
4 & Allium sativum L. & 763 & 0.603 & $620-938$ & 100 & 165.3 \\
5 & Anethum graveolens L. & 883.3 & 0.627 & $767-1023$ & 86.4 & 142.8 \\
\hline
\end{tabular}

$\mathrm{LD}_{50}$ values were calculated from the regression lines using method of Finney (1971)

Toxicity index according to Sun`s (1950)

Relative potency at fold according to Zidan and Abd El-Megeed (1988).

Table (3): Acute toxicity of tested insecticides against $4^{\text {th }}$ instar larvae of cotton leafworm, Spodoptera littoralis (Boisd).

\begin{tabular}{cccc}
\hline Treatment & $\mathbf{L C}_{\mathbf{5 0}} \mathbf{( p p m )}$ & Slope & Confidence limits(ppm) \\
\hline Cypermethrin & 10 & 0.627 & $7.256-13.788$ \\
Chlorpyrifos & 33.33 & 0.79 & $19.83-56.29$
\end{tabular}

$\mathrm{LC}_{50}$ values were calculated from the regression lines using method of Finney (1971)

Table (4): Acute toxicity of Cypermethrin and oils (1:1) mixtures against $4^{\text {th }}$ instar larvae of cotton leafworm, Spodoptera littoralis (Boisd).

\begin{tabular}{clccccc}
\hline No. & Treatment & $\begin{array}{c}\text { Lc } \mathbf{5 0} \\
\mathbf{p p m})\end{array}$ & Slope & $\begin{array}{c}\text { Confidence } \\
\text { limits of } \mathbf{L C}_{\mathbf{5 0}}\end{array}$ & $\begin{array}{c}\text { Toxicity } \\
\text { Index }\end{array}$ & $\begin{array}{c}\text { Relative } \\
\text { Potency at } \\
\text { fold }\end{array}$ \\
\hline 1 & Menth piperita L. & 1000 & 0.633 & $840-1195$ & 81.6 & 200 \\
\hline 2 & Syzygium aromaticum L. & 1055.5 & 0.503 & $727.9-1208.6$ & 52 & 127.4 \\
\hline 3 & Cinnamomum camphora L. & 1261 & 0.571 & $1096-1452$ & 40.8 & 100 \\
\hline 4 & Allium sativum L. & 763 & 0.603 & $620-938$ & 100 & 245.3 \\
\hline 5 & Anethum graveolens L. & 883.3 & 0.627 & $767-1023$ & 89.8 & 220.3 \\
\hline
\end{tabular}

$\mathrm{LD}_{50}$ values were calculated from the regression lines using method of Finney (1971)

Toxicity index according to Sun's (1950)

Relative potency at fold according to Zidan and Abd El-Megeed (1988). 
A. graveolens (89.8), M. piperita(81.6), $S$. aromaticum (52) and C. camphora (40.8)]. i.e. T.I was the highest in case of $A$. sativum (100) and the lowest value in case of $C$. camphora (40.8). The relative potency (R.P) values were arranged in a descending order as in the following: [A. sativum (245.3), A. graveolens (220.3), M. piperita (200), S. aromaticum (127.4) and $C$. camphora (100)]. i.e the highest R.P value was (245.3) in A. Sativum and the lowest value was (100) in C. camphora.

Acute Toxicity of Tested Mixture (1:1) of Chlorpyrifos $48 \%$ E.C and Five PlantOils Against $4^{\text {th }}$ Instar Larvae of cotton leafworm Spodoptera littoralis( Boisd).

Results in Table 5 show that $\mathrm{LC}_{50}$ values were arranged in a descending order as in the following Mixture :(Chlorpyrifos + Camphor oil), Mixture of (Chlorpyrifos + Clove oil), Mixture of (Chlorpyrifos + Dill oil), Mixture of (Chlorpyrifos + Mint oil) and Mixture of (Chlorpyrifos + Garlic oil) recording the following $\mathrm{LC}_{50}$ values: (1199.9, 808.3, 666.7, 641.6 and 449.9 ppm), respectively. So by other words the highest toxic Mixture was that of (Chlorpyrifos + Garlic oil) having $\mathrm{LC}_{50}$ equal to $449.9 \mathrm{ppm}$. and the lowest toxic Mixture was that of: (Chlorpyrifos + Camphor oil) having $\mathrm{LC}_{50}$ equal to 1199.9ppm. The toxicity index (T.I) values were arranged in a descending order as in the following: [A. sativum (100), M. piperita (70.1), A.graveolens (67.5),S. aromaticum (55.7) and C.camphora (37.5)]. i.e the highest value was 100 in A. sativum and the lowest value was 37.3 in C.camphora. In a similar trend, the relative potency (R.P) were also arranged in a descending order as in the following: [A. sativum (266.7), M. piperita (187.1), A.graveolens (180), $S$. aromaticum (148.8) and $C$. camphora (100)]. i.e the highest R.P was (266.7) A. sativum and the lowest value was (100) in C.camphora.

\section{DISCUSSION}

As it is obviously, the results of using plant-oils in treatment of $4^{\text {th }}$ instar larvae of cotton leaf worm Spodoptera littorlis (Boisd). That the Allium sativum has showed the most effective response and achieving that the highest mortality (\%) at all conc. 's tested. So that response was in an accommodation with the very early studies published Murthy and Amonkar (1974) and by Huang et al. (2000). Also results published recently by Ibrahim and El-Naser (2009) Isikber (2010), Mikaiel et al. (2011) Younes et al. (2011) and Douiri et al (2013), more over, recently studies by Sharaby and El-Nojiban (2015) and Chowdhury et al. (2016) where, all the previous studies assured the efficacy of garlic and achieving the highest activity against many spp's of insect pests (H.fly potato tuber moth, Red palm weevil, fungi, many lepidopterians and stored product insects). Where in the last one of insects, the garlic was used as a fumigant in the presence of $\mathrm{Co}_{2}$ affirming the concept of stereo fumigation.

The 2-nd oil followed the garlic in efficiency was the Menth piperita, where its efficiency and results of the present study was in an agreement with early studies by Zambnelli et al. (1996), Rezk and Gadelhak (1997), Seidilova and,Aggarwal et al. (2001), Algamal (2002). Also resent studies by Odeyem et al. (2008) and Younes et al. (2011) more over by very recently studies their results were relevant to results of the present study. And by throwing more light, where many spp.'s of insects, herbs, fungi, stored insects and pathogenic microorganisms. 
Table (5): Acute toxicity of chlorpyrifos and oils (1:1) mixtures against $4^{\text {th }}$ instar larvae of cotton leafworm, Spodoptera littoralis (Boisd).

\begin{tabular}{clccccc}
\hline No. & \multicolumn{1}{c}{ Treatment } & $\begin{array}{c}\text { Lc }_{\mathbf{5 0}} \\
\mathbf{p p m})\end{array}$ & Slope & $\begin{array}{c}\text { Confidence } \\
\text { limits of LC }\end{array}$ & $\begin{array}{c}\text { Toxicity } \\
\text { index }\end{array}$ & $\begin{array}{c}\text { Relative } \\
\text { potency at } \\
\text { fold }\end{array}$ \\
\hline 1 & Menth piperita L. & 1000 & 0.633 & $840-1195$ & 70.1 & 187.1 \\
\hline 2 & Syzygium aromaticum L. & 1055.5 & 0.503 & $727.9-1208.6$ & 55.7 & 148.4 \\
\hline 3 & Cinnamomum camphora L. & 1261 & 0.571 & $1096-1452$ & 37.5 & 100 \\
\hline 4 & Allium sativum L. & 763 & 0.603 & $620-938$ & 100 & 266.7 \\
\hline 5 & Anethum graveolens L. & 883.3 & 0.627 & $767-1023$ & 67.5 & 180 \\
\hline
\end{tabular}

$\mathrm{LD}_{50}$ values were calculated from the regression lines using method of Finney (1971)

Toxicity index according to Sun's (1950)

Relative potency at fold according to Zidan and Abd El-Megeed (1988).

The $3^{\text {rd }}$ oil followed mint was the Anethum graveolens, where the results of it in the present study are in an agreement with early studies by Eldoksch et al. (1991) and Algamal (2002). Also recently studies recorded by Ibrahim and El-Naser (2009), Mikhaeil (2011) and Vokk et al. (2011). More over very recently studies by Alsnafi (2014), Ja Eun et al. (2016) and Stanojevic et al. (2016). Where the studies confirmed that Dill oil was effective against $S$. littorlis and stored grain pests .Also the oil proved activity acting as (antimicrobial, antifungi, antibacterial, antiseptic, antiinflamatory and anticancer) agents. The $4^{\text {th }}$ oil followed dill was Syzygium aromaticum. That oil proved in its results which were showing a degree of similarity and correspondency as it was noticed in early studies by Chatterjee (1990), Rezk and Gadelhak (1997), Zhu et al. (2001), Algamal (2002) .Also recent studies carried out by El-Zemity and Ahmed (2005), Mahfuz and Khalequzzman (2007), Allahvaisi et al. (2011), Ashamo et al. (2012) and Fouad (2013). Also more recently studies fulfilled by Moawad $\boldsymbol{e t}$ al. (2015), Ebadah et al. (2016) and Bhatt et al. (2016). These studies confirmed the efficacy of clove oil against insects of Lepidoptera, stored product pests, termites and wax moth, beside no. of fungi showing a contact toxicity and chiefly fumigation effect. The Cinnamomum camphora was the $5^{\text {th }}$ one and the last one in the study. The efficiency and results of that camphor oil was in agreement with early studies Rezk Gadelhak (1997). Also dedected with a lot of authors' recently published El-Zemity and Ahmed (2005), Ibrahim and El-Naser (2009), Allahavaisi et al. (2011), Younes et al. (2011), Osman et al. (2012) and Fouad (2013). Moreover very recently studies by Dhen et al. (2014), Jun Hyung and Isman (2015) and Bhatt et al. (2016). Anticipating and proving in their studies the efficiency of applying the camphor with insect of Lepidoptera leaf - hoopers caterpillers- stored grain insects and against mites. And by throwing more light on the use of these plant-oils as an alternatives to synthetic pesticides and the characteristics of these oils possessing a potential pesticidal action and the expected ways of causing the toxic action (i.e mode of action) against the target pests. Also, you can say in other words that time of exposure, dosage and fumigant toxicity of these used oils are very efficient and dependent factors (El-Nahal et al., 1989). Also these oils proved to have a contact and fumigant toxicity Huang et al. (2000). And by going 
on and more deep in details, it was noticed that there is a direct and positive proportion between susceptibility of contact toxicity and age of target (larvae) and not only that but also it was confirmed that the complete constituents of the plant-oils is much higher and efficient than the use of each, constituent separately and alone Ohkawa $\boldsymbol{e t}$ al. (2007). Also to know something about its expected mechanism mode of action, where the oil have certain physical effect via penetration of the cuticle and their insect's integuments causing a membrane disruption in all target pests .Also a blockage of tracheal system and affecting nervous system and its specific constituents and neurotransmitters (Ohkawa et al., 2007). And by more focus, it was noticed and proved that the susceptibility to plantoils depends on chiefly insect spp's and plant families of these oils, especially Fam. Apiaceae-Fam./Lamiaceae, Fam./Lauraceae and Fam./Myrtaceae, reflecting their possessing the specific phytochemicals of each one and showing a high efficiency and significancy in causing their contact and fumigant toxicity, Rajendran and Sriranjini (2008). Recently some plant-oils act as a J.H.`s Younes et al. (2011) and more recently Douiri et al. (2013) declared that the essential oils could be considered as an IPM tactic scenario without or with at least possible risk hazards to man and its environment with all its constituents. On the other side (i.e $\mathrm{LC}_{50}$ of plant-oils), it was noticed that the results of the present study were showing similarity and an agreement with the results recorded by Mansour et al (1995). Eldoksch and Abdel-Rassol (1995), El-Gendy et al. (2004), El-Zemity and Ahmed (2005), El-Araby (2014), Farid et al. (2014), Sharaby and El-Nojiban (2015) proving that contact toxicity> stomach toxicity. In case of tested insecticides the obtained results about the acute toxicity of chlorpyrifos and cypermethrin were in an agreement with the results published by Sharaf et al. (1995) and Eldoksch and Abd El-Rassol (1995). By other words, the cypermethrin was much more toxic than chlorpyrifos. In a No. of early studies, the use of mixtures of some promising plants or plant-oils (e.g.camphor- garlic- clove- dill - citrus ... etc.) and various insecticides belonging to different chemical groups (e.g, o.p.'scarbamates - synthetic pyrethroids) These mixtures applied on many pests (e.g cotton leaf worm - stored grain - cut worm -soya bean borers, citrus leafminor- c. pipens ... etc.) The use of these mixtures and the aim of these control tactics, were confirmed in many studies, Lichtenstein et al. (1974), Eldoksch et al. (1991), Guirguis et al. (1991), Taman (2002), Hussein et al (2005), Abhilash and Patil (2006), Elkhodary et al. (2007), Mesbah et al. (2007), Chandla and Chandel (2007) and Besheli (2008). The chemical insecticides are currently the method of choice to protect crops from insect damage, however, there widespread use has led to the development of resistant strains, to most of all synthetic insecticides. So the use of mixtures of insecticides from different chemical groups or by use of plant extracts, oils and other additive was the possible solution to avoid resistance criterion, and actually emphasizing the use of more safe alternatives (El-Araby, 2008). Ideally the insecticides having different modes of action mixed on the assumption that they would complement the action of each other for killing the target pest. When two compounds are mixed, they can be either potentiating. Or an additive or antagonistic effect in an insect spp. 's. These effects can be varied on different insect spp's or strains depending upon their physiology and mechanism (S) of resistance developed. So, in this case there may be a potential for reducing the application rate of one of both components, of the mixture [El-Aswad (2007) and Osman et al. (2012)] so and by respecting the principle and need for reducing the field doses of synthetic 
insecticides, enhancing the role of beneficial insects and reduce the cost of pest control [Ismail et al. (2012)] and by going more deep, pest control by direct or indirect use of essential oils is a promising approach. Very recently the proof of the presence of essential oils in members of many plant Fam.'s (e,g. Fam: Rutaceae) besides other fam's evaluated previously and confirming the need and demand to be valid and having a real value to be as a natural source of botanical insecticides. [Thodsare et al., 2014)]. Also essential oils can be used as a potential control agents against potato beetles [Saroukolai et al., 2014)]. Several essential oils with insecticidal properties have been evaluated on biological, physiological and behavioral parameters upon Spodoptera spp's [Cruz et al., 2015; Jun Hyung and Isman, 2015). showed that the synergistic interactions between constituents of essential oils elucidating, the lowering of surface tension as well increased solubility of camphor by 1.8 cineole and explaining the enhanced penetration of camphor. And due to the similarities in biological function of animal and microbial membranes. These finding potential for application in other field of study .these findings showed a similarity of attitude and so an agreement with the obtained results in this study. Moreover and throwing more light, the need for a promising toxic mixture reflecting the validity and importance of effective alternatives, so for increasing their toxicity and decreasing insect resistant buildup. (Sharaby and El-Nojiban, 2015). The resistance - negative impacts on non target organisms and residues in food of synthetic pesticides, necessitates the development of environmentally safe products for use in pest control Ribeiro et al. (2015), Abdelgaleil et al. (2015), Barakzai and Lyall (2014), Sahak and Hement (2013), Derbalah, et al. (2012) and Isikber (2010). The present study was generally in an agreement with these results and showing different responses according to the plant oils used and bioassay system applied JaEun et al. (2016), Bhatt et al. (2016) and Chowdhury et al. (2016). So finally we can conclude that it is a concept of an ecofriendly approach and no residual effect and not acting as a source of possible hazardous and impact effects to environment also it could be a new important tool in IPM programs.

\section{REFERENCES}

Abdelgaliel, S.A.M.; Abdel-Aziz, N.; Sammour, E.A.; El-Bakry, A.M. and Kassem, S.M.I. (2015). Use of Tankmix adjuvants to improve effectiveness and persistence of chlorpyrifos and cyhalothrin formulations. J. Agr. Sci. Technol., 17: 1539-1549.

Abhilash, C. and Patil, R.H. (2006). Comparative efficacy of new insecticides, botanicals and insect growth regulators against the pod borer complex of soybean. Res., 4(1/6): 69-72.

Aggarwal, K.K.; Tripathi, A.K.; Ahmed, A.; Prajapati, V.; Verma, N. and Kumar, S. (2001): Toxicity of Lmenthol and its derivatives against four storage insects, Int. J. Tropical Insect Sci., 21 (3): 229-235.

Algamal, M.A. (2002). The biological efficiency of some plant extracts MSc. thesis. Fac. Agric., Alex. Univ., 150.

Allahvaisi, S.; Maroufpoor, M.; Abdolmaleki, A.; Hoseini, S.A. and Ghasemzadeh, S. (2011). The effect of plant oils for reducing contamination of stored packaged-foodstuffs. J. Plant Prot. Res., 51 (1): 82-86.

Al-Snafi, A.E. (2014). The pharmacological importance of Anethum graveolens. A review. Int. J. Pharm. and Pharm. Sci., 6 (4): 11-13.

Ashamo, M.O.; Odeyemi, O.O. and Aringbangba, R.O. (2012). Insecticidal 
activity of Eugenia aromatic L. against the Angoumois grain moth, Sitotroge cerealella (Olivier), in rice paddies. IOBC/WPRS Bulletin, 81: 73-81.

Barakzai, A.W. and Lyall, H. (2014). Efficacy of botanical insecticides in management of okra shoot and fruit borer, Earias vittella (Fab). Ann. Plant Prot., Sci., 22 (2): 339-341.

Besheli, A.B. (2008). Efficacy of Bacillus thuringiensis, mineral oil, insecticidal emulsion and insecticidal gel against Phyllocnistis citrella stainton (Lepidoptera: Gracillariidae) Plant Prot. Sci., 44 (2): 68-73.

Bhatt, P.; Nitin, T. and Srivastava, R.P. (2016). Insect growth regulatory activities from oils of camphor and clove against Spilosoma oblique. J. Appl. and Nat. Sci., 8 (3): 1434-1437.

Conway, G.; Norton, G.A.; Cominsi, H.N.; Patton, S. and Graig, I.A. (1982). Pesticide Resistance and World Food Production. ICCET Imperial College, London, U.K., 144.

Chandla, V.K. and Chandel, R.S. (2007). Integrated management of soil pests of potato in higher hills of Himachal paradesh. Nat. Acad. Sci. Letters, 30 (7/8): 221-222.

Chowdhury, H.; Gotyal, B.S.; Selvaraj, K. and Sarkar, S.K. (2016). Bioefficacy of plant extracts on stem rot, Macrophomina phaseolina (Tassi) Goid and Bihar hairy caterpillar. J. Appl. and Nat. Sci., 8 (1): 191-195.

Chatterjee, D. (1990). Inhibition of fungal growth and infection in maize grains by spice oils. Lett. Appl. Microbiol., 11: 148-151.

Cruz, G.S.; Teixera, V.W.; DE Olivera, J.V.; Teixera, A.A.C.; ArAuJo, A.C.; Alves, T.J.S.; D.A. Cunha, F.M. and Breda, M.O. (2015). Histological and histochemical changes by clove essential oil upon the gonads of Spodoptera frugiperda (JE Smith) (Lepidoptera: Noctuidae). Int. J. Morphol, 33 (4): 1393-1400.

Derbalah, A.S.; Morsey, S.Z. and EISamahy, M. (2012). Some recent approaches to control Tuta absoluta in tomato under greenhouse conditions. Afr. Entomol., 20 (1): 27-34.

Dhen, N.; Majdoub, O.; Souguir, S.; Tayeb, W.; Laarif, A. and Chaieb, I. (2014). Chemical composition and fumigant toxicity of Artemisia absinthium essential oil against Rhyzopertha dominica and Spodoptera littoralis. Tunisian J. Plant Pro., 9 (1): 57-65.

Douiri, L.F.; Boughdad, A.; Assobhei, O. and Moumni, M. (2013). Chemical composition and biological activity of Allium sativum essential oils against Callosobruchus maculates, IOSR. J. Environ. Sci., Toxicol. and Food Technol. (IOSR-JESTFT), 3 (1): 30-36.

Ebadah, I.M.; Shalaby, S.E.M. and Moawad, S.S. (2016). Impact of certain natural Plant oils and chemical insecticides against tomato insect pests. J. Entomol., 13 (3): 84-90.

El-Araby, R.E. (2008). Studies on some wiled Botanicals and Natural Pesticides in North Sinai, M.Sc., Fac. Environ. Agric. Sci. Suez Canal Univ., Egypt.

El-Araby, R.E. (2014). Comparative Study of Biochemical and Ecotoxicological Effects Insecticides and Potential Alternatives on controlling stored grain pests, Ph.D. Thesis, Fac. Environ. Agric. Sci., Suez Canal Univ., Egypt.

El-Aswad, A.F. (2007). Efficiency of certain insecticides and insect growth alone or in mixture with chlorpyrifos for the Integ. Control of the Egyptian cotton leafworm. J. Pest. Cont. and Environ. Sci., 15 (2): 29-48. 
El-Defrawi, M.E.; Toppozada, A.; Mansour, N. and Zeid, M. (1964). Toxicological studies on the Egyptian cotton leafworm, Prodenia Litura.1Susceptibility of different larval instars of proteins to insecticides. J. Econ., 57: 591-593.

Eldoksch, H.A. and Abdel-Rassol, M.A. (1995). Toxicity and synergism of some plant extracts and insecticides against European corn born Egg-masses (Lepidoptera: Pyralidae). Alex. Sci. Exch., 16 (4): 495-502.

Eldoksch, H.A.; Radwan, M.A. and AboEIFadl, I.A. (1991). Antifeedin and synergistic activity of chenopodium and dill extracts and pure carvone on Spodoptera littoralis (Boisd.) (Lepidoptera: Noctuidae). Com. Sci. and Dev. Rev., 33: 249-263.

El-Gendy, K.; Kenawy, A.; El-Bakary A. and Elsebae, A.H. (2004). Safe alteratives of pesticids for pest mangement of Tribolium confusum J. Pest. Cont. and Environ. Sci., 12 (1/2): 13-26.

El-Khodary, A.S.; Samy, M.A.; Keratum, A.Y. and El-Fakharany, S.K.M. (2007). Toxicity of pesticides and oil plant extracts to plant sucking pests. J. Pest Cont. and Environ. Sci., 15 (2): 49-61.

El-Nahal, A.K.M.; Schmidt, G.H. and Risha, E.M. (1989). Vapours of Acorus calamus oil-A space treatment for stored-product insects, J. Stored Prod. Res., 25 (4): 211-216.

El-Sebae, A.H. (1987) Biotechnology in pest control with special reference to natural products. Proceedings of $2^{\text {nd }}$ Nat. Conf of pests and dis. of veg. and Fruits Ismailia, 19-38.
El-Zemity, S.R. and Ahmed, S.M. (2005). Antifungal activity of some essential oils and their major chemical constituents against some phytopathogenic fungi. J. Pest Cont. and Environ. Sci., 13 (1): 6172.

Farid, D.S.M.; Yosry, M.A. and Aly, A.E. (2014). Some herbal, medicinal products as asource of promising natural pesticides, MSc. Thesis, Fac. Environ. Agric. Sci. Suez Canal Univ., Egypt.

Finney, D.J. (1971). Probit Analysis, $3^{\text {rd }}$ Ed. Cambridge Univ. Press, Cambridge, England.

Fouad, H.A. (2013). Effect of five essential oils as repellents against the cowpea beetle, Callosobruchus (F.), Bulletin of Environ., Pharmacol. and Life Sci. (BEPLS), 2 (5): 23-27.

Guirguis, M.W.; Gouhar, K.M.; Watson, W.M.; Ibrahim, N.A. and Salem, R. (1991). The toxic action of volatile oils extracted from citrus fruit peels against different insect pests. Egypt. J. Agric. Res., 69 (1): 163-177.

Huang, Y.; Lam, S.L. and Ho, S.H. (2000). Bioactivities of essential oil from Elletaria cardamomum L. Maton. to Sitophilus zeamais M. and Tribolium castaneum H., J. Stored Prod. Res., 36 (2): 107-117.

Hussein, H.I.; Al-Rajhy, D. and AlAssiry, M. (2005). Toxicity of four pyrethroid-based insecticides and kerosene to a laboratory population of Culex pipiens. Pakistan J. Biol. Sci., 8 (5): 751-753.

Ibrahim, M.Y. and El-Naser, Z. (2009). Study of efficacy of some extracts, oils inert dusts against Cowpea Weevil, Callosobruchus maculates FAB. (Colleoptera; Brucheidae) on Chickpea Seeds. The Damascus Univ. J. Agric. Sci., 25 (1): 107-120. 
Isikber, A.A. (2010). Fumigant toxicity of garlic essential oil in combination with carbon dioxide $(\mathrm{CO}<\mathrm{sub}>2</$ sub $>)$ against stored-product insects. Julius-Kuhn-Archiv, (425): 371-376.

Ismail, S.M.; Shaker, N. and Morshedy, M. (2012). Evaluation of some compounds on Spodoptera littoralis larvae. Alex. J. Agric. Res., 57(3): 213-219.

Ja-Eun, S.; Kim, J.M.; Lee, N.H.; Yang, J.Y. and Lee, H.S. (2016). Acaricidal and insecticidal activities of essential oils against a stored-food mite and stored-grain insects. J. Food Prot., 79 (1): 174-178.

Jun Hyung, T. and Isman, M.B. (2015). Enhanced cuticular penetration as the mechanism for synergy of insecticidal constituents of rosemary essential oil in Trichopl usiani. Sci. Reports, 5 (12690): srep 12696.

Lichtenstein, E.P.; Liang, T.T.; Schuilz, K.R.; Schnoes, H.K. and Carter, G.T. (1974). Insecticidal and synergistic components isolated from dill plants. J. Agric. Food Chem., 22 (4): 658-664.

Mansour, A.S.; Messeha, SH. and Hamed, M.S. (1995). Botanical larvae and mosquitofish in laboratory. $3^{\text {rd }}$ Cong. Toxicol. Dev. Count. Cairo, Egypt, 369380 (19-23 Nov.).

Mahfuz and Khalequzzaman, M. (2007). Contact and fumigant toxicity of essential oils against Callosobruchus maculates, Univ. J. Zool. Rajshahi Univ., 26: 63-66.

Mesbah, H.A.; Saad, A.S.; Mourad, A.K.; Taman, F.A. and Mohamed, I.B. (2007). Joint Action of quercetin with four insecticides on the cotton Leafworm larvae, Spodoptera littoralis Boisd. (LEp.: Noctuidae) in Egypt. Comm. Appl. Biol. Sci. Ghent Univ., 72 (3): 447-459.

Mikhaiel, A.A. (2011). Potential of some volatile oils in protecting packages of irradiated wheat flour against Ephestia
Kuehniella and Tribolium castaneum. J. Stored Prod. Res.; 47(4): 357-364.

Moawad, S.S.; El-Behery, H.H. and Ebdah, I.M. (2015). Effect of volatile oils on some biological aspects of Galleria mellonella L. and its parasitoid species, Bracon hebetor Say. (Hymenoptera: Braconidae). Egyptian J. Biol. pest Cont., 25 (3): 603-607.

Murthy, N.B.K. and Amonkar, S.V. (1974). Effect of a natural insecticide from garlic (Allium Sativum L.) and its synthetic form (diallyl-disulphide) on plant. Indian J. Experi. Biolo., 12 (2): 208- 209.

Odeyem, O.O.; Masika, P. and Afolayan, A.J. (2008): Insecticidal activities of essential oil from the leaves of Mentha longifolia L. subsp.capensis against Sitophilus zeamais (Motschulsky) (Coleoptera: Curculionidae), Afri. Entomol., 16 (2): (220-225).

Osman, H.H.; Fetoh, B.E.A. and Mohammad, A.M. (2012). The potency of chloropyrifos and camphor extract on Spodoptera littoralis (Boisd). Egyptian Academic Journal of Biological Sci. Entomol., 5(2): 131-139.

Ohkawa, H.; Hisashi, M. and Philip, W.L. (2007). Pesticide Chemistry, Wiley-VcH Verlag Gmbh and co. KGa A. pp. 450.

Pesticide Manual, $17^{\text {th }}$ Ed. (1983). British Crop Protection Council.

Rajendran, S. and Sriranjini, V. (2008). Plant products as fumigants for storedproduct insect control., J. Stored Prod. Res., 44 (2): 126-135.

Rezk, H.A. and Gadelhak, G.G. (1997). Impact of four plant oil- extracts on the control of the Parasitic/mite, Varroa jacobsoni oudemans (ACARI: mesotig mata). Alex. J. Agric. Res., 42 (2): 105113. 
Ribeiro, R.C.; Zanuncio, T.V.; Ramalio, F. de S.; Silva, C.A.D. da; Serrao, J.E. and Zanuncio, J.C. (2015). Feeding and oviposition of Anticarsia gemmatalis (Lepidoptera: Noctuidae) with sublethal concentrations of ten condiments essential oils. Indust. Crops and Prod., 74: 139-143.

Sahak, K.A. and Hemant, L. (2013). Efficacy of chemical and plant products in management of Earias vittella Fab. on okra. Ann. Plant Prot. Sci., 21 (2): 283285.

Saroukolai, A.T.; Gadir, N.G.; Hooshang, R. and Javad, H. (2014). Antifeedant activity and toxicity of some plant essential oils to colorado potato beetle, Leptinotarsa decemlineata Say (Coleoptera: Chrysomelidae). Plant Prot. Sci., 50 (4): 207-216.

Shalaby; G.A; Bassyouni, A.M. and Metwally, M.M. (2005). Effectiveness of certain plant extracts against insect pests and predators in sugarbeet fields. Egypt. J. Agric. Res., 83 (3):1191-1198.

Sharaby, A. and El-Nojiban, A. (2015). Evaluation of some plant essential oils against the black cutworm Agrotis ipsilon. Global J. Adv. Res., 2 (4): 701711.

Sharaf, F.H.; El-Basyouni, S.A. and ElBasyouni, S.A. (1995). Insecticide Resistance Management 1-Studies on the Egyptian cotton leafworm Spodoptera littoralis (Boisd). Com. in. Sci. and Dev. Res., 51 (769): (87-103).

Stanojevic, L.P.; Mihajlo, Z.S.; Dragan, J.C.; Bojana, R.D. and Jelena, S.S. (2016). Dill (Anethum graveolens L.) Seeds essential oil as a potential natural antioxidant and antimicrobial agent. Biologica Nyssana, 7(1): 31-39.
Sun, Y.P. (1950). Toxicity index: an improved method of comparing the relative toxicity of insecticides. J. Econ. Entomol., 43: 45-53.

Taman, F.A. (2002). The synergestic effect of quercetin to different insecticides on Spodoptera littoralis (Boisd). Alex. Sci. Exch., 23 (1):17-23.

Thodsare N.H.; Bhatt, P. and Srivastava, R.P. (2014). Bioefficacy of Murraya koenigii oil against Spilosoma oblique and Spodoptera litura. J. Entomol. and Zool. Studies, 2(4): 201-205.

Vokk, R.; Lougas, T.; Mets, K. and Kravets, M. (2011). Dill (Anethum graveolens L.) and parsley (Petroselinum crispum (Mill.) Fuss) from Estonia: Seasonal differences in essential oil composition. Agron. Res., 9: 515-520.

Younes, M.W.F.; Salah El. O.; Mohamed A.E.; Nabila S.Y. and Gihan A.O. (2011). Effect of seven plant oils on some biochemical parameters in khapra beetle Trogoderma granarium Everts (coleoptera : dermestidae) Egypt. J. Exp. Biol. Zool., 7 (1): 53-61.

Zambnelli, A., D'Aulerio, A.Z.; Bianchi, A. and Albasini, A. (1996). Effects of essential oils on phytopathogenic fungi in vitro. J. Phytopathol, 144: 491-494.

Zhu, B.C.G. Henderson; Chen, F.; Fei, H. and Laine, R.A. (2001). Evaluation of vetiver oil and seven insect-active essential oils against the Formosan subterranean termite. J. Chem. Ecol., 27 (8): 1617-25.

Zidan, Z.H. and Abd El-Megeed, M.I. (1988). New Approaches in Pesticides and Insect Control. Arabic publishing House and Delivery., Cairo, 60pp. (In Arabic Language). 


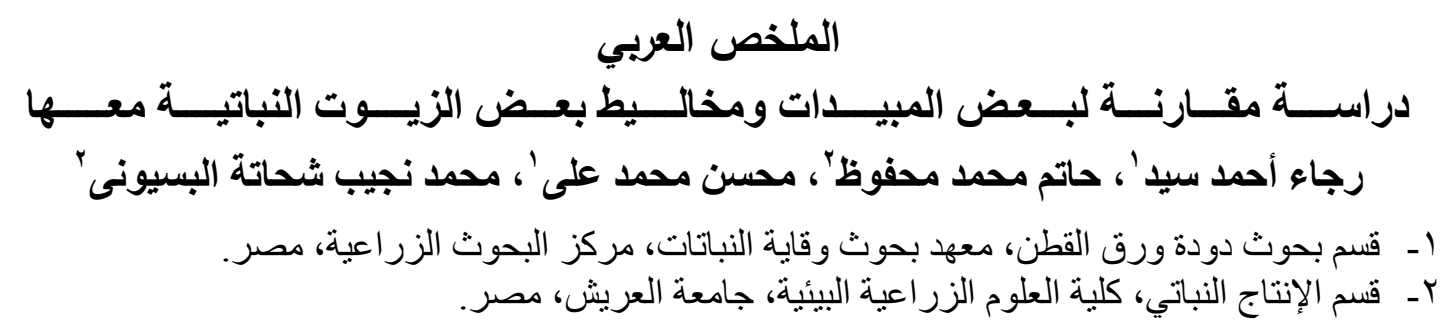

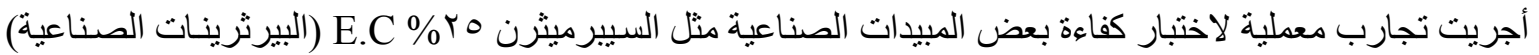

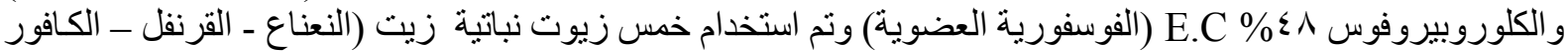
- الثوم - الثبت) وتم تقدير كفاءة LC

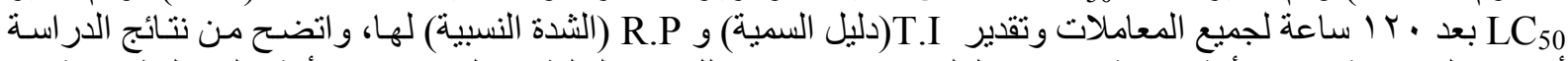

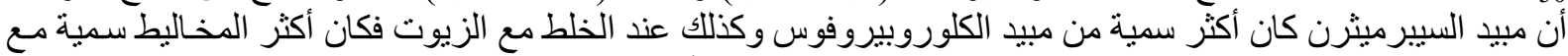

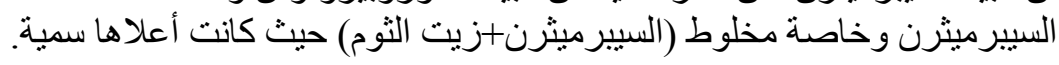
الكلمات الإسترشادية: المبيدات الفعالة، النعناع، القرنفل ،الكافور، الثوم، الثبت، مخاليط الزيوت النباتية. 
